\title{
Jesus: Eschatological prophet and/or wisdom teacher?
}

\author{
W S Vorster \\ University of South Africa
}

\begin{abstract}
The words and works of Jesus the Galilean can be interpreted against the background of different possible roles. These include prophet, teacher, magician and healer. This essay addresses the question whether he was an eschatological prophet or a wisdom teacher, or perhaps a combination of both. The implications of placing Jesus in these roles are worked out in the essay, which is the second of a series of two essays on Jesus the Galilean. Attention is also paid to the nature of the sources which make it possible to fit Jesus into different roles.
\end{abstract}

In my previous essay (Vorster 1991:121-135) on the question of Jesus' identity, I concentrated on the reasons for the apparent confusion in the answers to the question, and also paid attention to the phrase Jesus the Galilean. It was an attempt to draw attention to the difficulties involved in trying to answer the question of who Jesus was, and indicate the importance of finding an answer to the question within a first-century Palestinian context. I underscored the need for rigorous historical investigation and an awareness that historical criticism always involves construction of images. In fact, I asserted that the historical Jesus problem teaches us that our views on who Jesus was or, for that matter, who he is, are based on different assumptions and convictions.

This essay deals with three possible answers to the question of who Jesus was. I will discuss the question of whether Jesus was an eschatological prophet, a wisdom teacher, or perhaps both. It is an attempt to get to grips with the different images of Jesus which currently dominate New Testament scholarship. These images are

\footnotetext{
* This essay is a reworked version of the C B Powell public lecture held during August 1990 in Pretoria.
} 
forced upon us by the New Testament as well as by the results of New Testament scholarship. I would furthermore like to emphasise the fact that there are currently other images defended by scholars, such as the liberator of the oppressed, a revolutionary, and so on. To my mind, however, both the state of scholarship and the images of Jesus in the ancient sources at our disposal make it necessary for us to take seriously the images of prophet and teacher. The implications of viewing Jesus as eschatological prophet and/or wisdom teacher will become clear by the end of this essay.

I will first, at some length, discuss some of the reasons why there are currently two opposing images of Jesus among New Testament scholars, namely the images of Jesus as an eschatological prophet or a wisdom teacher. These two images will then be discussed separately in the next two sections of my essay. In the end an answer will have to be given to the question of whether it is necessary to put the images in opposition. An attempt will be made to deal with these matters within the context of first-century Palestine, and not simply within the framework of twentieth-century thought.

\section{WHY TWO OPPOSING IMAGES?}

One of the main reasons for the opposing views on Jesus' identity, is that the nature of our sources on Jesus makes it possible to have different views. The Gospels are our main sources. These documents were written forty or more years after the death and resurrection of Jesus, and they are in no way to be viewed as history books in the modern sense of the word. No single Gospel gives us a historical account of the life and works of Jesus in an exact, chronological and word-for-word manner.

Until the beginning of this century it was thought that Mark's gospel was the oldest of the four, and that it gave us a reliable picture of who Jesus was. It became clear, however, that the Gospel of Mark, like the other Gospels, had given us an image of Jesus constructed by its author for a specific audience in a specific situation and for a specific purpose, even though he made use of traditional material. Mark did not invent all the material he used in writing his Gospel. On the contrary, he made use of sayings of Jesus, stories about him and the things he did, but he cast this material into his story of Jesus in order to communicate something about Jesus to his audience. He also invented some of the material he wrote about Jesus and ascribed it to Jesus. In this manner he created an image of Jesus to fit his own purpose and needs. The same holds true for the authors of the other Gospels who, like Mark, told their stories about Jesus from a post-resurrection perspective for their own purposes. 
The Gospels presuppose a history of growth and a process of transmission of material about Jesus, his life, the things he did and said. How the making of the Gospels exactly took place is not altogether clear. Whether Mark, for example, had all sorts of written material at his disposal and whether he compiled his story from this by including some and omitting other material is not known. It is normally thought that he relied greatly on oral tradition about Jesus, and that his Gospel grew out of this source. Be that as it may, for our purpose it is necessary to keep in mind that the image of Jesus of the Gospel in Mark is Mark's image, and that he used the works and sayings of Jesus to create that image. Some of the sayings and deeds which we find in the Gospels are not authentic. They were ascribed to Jesus by early Christians who did not entertain the fears we do concerning historical "correctness'. These people used the material about Jesus to inform others about his significance and not about the historical question of his exact identity. This explains why they changed some of his sayings and used others in totally different contexts.

In addition, one also has to keep in mind the relationship between the Gospels of Matthew, Mark and Luke, often referred to as the synoptic problem. These Gospels are called synoptic, that is, 'seeing together', because they are so similar. They tell the story of Jesus to a large extent in the same sequence, and with a great similarity in wording. These similarities are normally explained by literary dependence. One author copied from another, and used the material for his own story. There is, nevertheless, a substantial amount of material which cannot be explained in this way. Matthew and Luke have a lot of material in common, which does not appear in Mark. If Mark's gospel is the oldest of the three, and if Matthew and Luke used Mark, as is often argued, they must have made use of a common source consisting mainly of the sayings of Jesus, as well as of other sources at their disposal. This is called the two-source hypothesis. It may be schematised as follows:

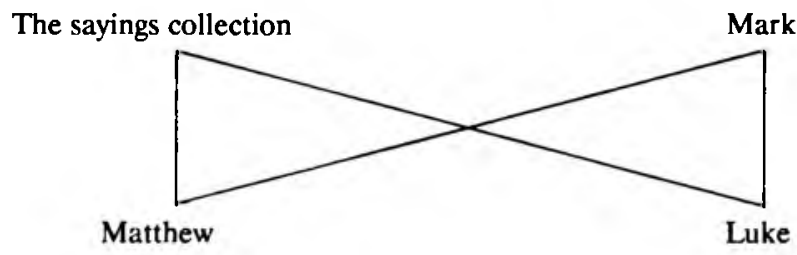

This process of the formation of the Gospels is important for historical construction of who Jesus was. If we take into account the hypothetical 'Sayings collection', normally called Q - from the German word 'Quelle', the equivalent for 'source' - we have at least four broad images of Jesus. $Q$ leaves the impression that Jesus was a 
teacher, a speaker of aphorisms - that is, pithy sayings expressing general truths while Mark, for example, who also lays emphasis on Jesus as a teacher, portrays Jesus as the suffering Son of God. So, who was Jesus?

The question becomes far more challenging when we notice that certain sayings of Jesus are given in different contexts and that the same material is used for different purposes by the authors of our sources. Even the Lord's Prayer is given in two versions in Matthew and Luke. This means that the Jesus tradition was used and interpreted after his death in different contexts for different purposes, and also that the present-day historian has to interpret this material very carefully to construct an image of Jesus. It implies that the images we get of him from the tradition as we find it in the Gospels, can be different from the Jesus who once walked the earth. Jesus the Galilean need not necessarily have been the apocalyptic figure that Mark portrays (see Mack 1987).

In addition to the difficulties caused by the nature of our sources, there also is the history of interpretation of these sources which has its own implications for answering who Jesus was. For almost a century Jesus has been interpreted within the framework of Jewish eschatology and apocalyptic (see Perrin 1963). Both his teaching and who he was came to be seen within the framework of the expectation of the end of the world, the last judgement, the resurrection and his second coming or parousia.

In many circles, if not in most, the eschatological interpretation of the teaching of Jesus and of Jesus as an eschatological prophet became dominant. During recent times a growing number of scholars, especially in the United States, however, have started questioning the eschatological framework in which Jesus and his teaching have been placed during the twentieth century (see Borg 1986; Mack 1987). It has been argued that the idea of apocalyptic eschatology in the teaching of Jesus was a later development in the Jesus tradition, and that Jesus himself was probably more of a sage than an eschatological prophet. A new frame of understanding is developing, making it clear that it is possible to conceive of Jesus as a wisdom teacher in non-eschatological terms. The Jesus tradition lends itself to both interpretations and it remains to be argued which is the more authentic in terms of the earthly Jesus. Let us briefly pay attention to a few of Jesus' sayings in this regard, to illustrate how his teaching can be interpreted within an eschatological or a wisdom framework.

The so-called Beatitudes of Jesus are well attested (see Mt 5:3-11; Lk 6:20-23) and are normally regarded as part of the authentic sayings of Jesus - not necessarily in their present number and form, but in general. Matthew's version reads as follows: 
Happy are those who know they are spiritually poor;

The Kingdom of heaven belongs to them!

Happy are those who mourn;

God will comfort them!

Happy are those who are humble;

they will receive what God has promised!

Happy are those whose greatest desire is to do what God requires;

God will satisfy them fully!

Happy are those who are merciful to others;

God will be merciful to them!

Happy are the pure in heart; they will see God!

Happy are those who work for peace; God will call them his children!

Happy are those who are persecuted because they do what God requires; the Kingdom of heaven belongs to them!

Happy are you when people insult you and persecute you and tell all kinds of evil lies against you because you are my followers. Be happy and glad, for a great eward is kept for you in heaven. This is how the prophets who lived before you were persecuted.

(TEV)

How should we interpret these sayings? Are they apocalyptic blessings or conditions for entering the Kingdom (see Guelich 1976)? If we take the term 'kingdom of heaven', which is the Matthean expression for 'kingdom of God', to refer to the apocalyptic reign of God and the coming of a new world, these sayings should be regarded as apocalyptic blessings. The poor, the humble and those of similar status will be blessed by God when the new world starts. The roles will be overturned as Luke says. Those who are happy will be those who are sad! But is it necessary to interpret these sayings from an apocalyptic perspective? Should they not rather be interpreted as general truths in kingdom terminology? Think of the Old Testament Proverbs where we have the proverbs and maxims of a sage comparable to the Beatitudes. Did Jesus not attempt to bring about a revolution in values among people who were distressed and oppressed? Will the peacemakers not be those who take 
upon themselves the task of the ruling class who normally bring about peace? Did he not try to create a new frame of reference, a new value system, by expressing his views in terms of practical skills to cope with life? If so, these sayings of Jesus could be interpreted as the sayings of a sage and not necessarily as apocalyptic blessings.

The Beatitudes are but one of many examples of how it is possible to interpret the sayings tradition of Jesus within a wisdom framework and not an apocalyptic, eschatological one. This simply implies that it is possible to interpret the Jesus tradition in ways that differ from the current dominating prophetic eschatological manner. But we are not ready to argue a case for or against an eschatological or a wisdom image of Jesus. Let us now consider the two images separately.

\section{JESUS THE ESCHATOLOGICAL PROPHET}

According to the New Testament, Jesus was viewed by some as a prophet (Mt 21:11; Jn 4:19; 9:17; see Mk 8:28). With reference to himself Jesus said: 'A prophet is respected everywhere except in his home town and by his own family' (Mt 13:57 TEV).

He started his career by being baptised by, and becoming a follower of John the Baptist, who was an apocalyptic prophet. According to Mark (1:14-15), he then set off to preach the gospel in Galilee. His teaching contains sayings which are comparable to the sayings of prophets. Like the prophets of old he made statements about current situations, he preached and made known the will of God. According to the synoptics he predicted future events (see Mk 13 par) and behaved like a prophet. This and many other reasons explain why scholars often argue that Jesus was probably an eschatological prophet, who proclaimed the imminent coming of the kingdom (see Hengel 1981; Sanders 1985).

Since there is general agreement about the central place of the kingdom of God in the teaching of Jesus, and also that eschatology and apocalyptic were dominant features of Jewish thought in the time of Jesus, New Testament scholars have accepted the eschatological nature of the teaching of Jesus as an axiom, and Jesus has been conceptualised in terms of a Jewish eschatological or apocalyptic prophet for the past hundred years. It simply means that Jesus was seen as somebody who understood his ministry in terms of Jewish eschatological expectations, in fact as the eschatological prophet.

Eschatology has to do with the last things, that is, the end of the world, death, afterlife, a new world and so on. Although the term is not used consistently by biblical scholars, and in the case of Jesus is often used synonymously with apocalyptic, one should not get the impression that there was only one eschatological or apocalyptic view in the time of Jesus. For our purpose we will use the term eschatology in this essay to refer to the Jewish expectation that the world will come to an 
end, including the last judgement, resurrection, and dawn of a new age (see Borg 1986:81).

'Prophet' is used in the sense of somebody who is regarded or who sees him/ herself as a person who serves as a means of communication between the divine and the human worlds (Wilson 1985:826). Prophetism concerns the past, present and the future, and prophets express themselves about all three these aspects of time. Being an eschatological prophet therefore means being informed about the past, present and future with relation to the will and plans of God. In order to understand the image of Jesus as an eschatological prophet, it is necessary to rehearse briefly the history of interpretation of Jesus within an eschatological, apocalyptic framework.

Before the publication of the epoch-making book of Johannes Weiss on the preaching of Jesus on the kingdom of God, the kingdom was explained solely on ethical grounds. According to Ritschl, Jesus 'saw in the Kingdom of God the moral task to be carried out by the human race' (see Perrin 1963:16). Weiss severely criticised these views and argued that Jesus was convinced that he was standing at the end of the world and the end of history, and that the judgement was at hand. The kingdom of God was an apocalyptic concept, according to him; it was a future event which was on the verge of coming.

It was, however, the renowned Albert Schweitzer who interpreted and propagated some of these ideas of Weiss, and who challenged nineteenth-century research into the historical Jesus by focusing on the imminence of the kingdom of God.

Schweitzer believed that the wholc life, work and teaching of Jesus was dominated by his expectation of the end of the world as we find it in Jewish apocalyptic. This expectation influenced Jesus' ethical teaching, which Schweitzer called 'interim-ethics'. It means that the ethics of Jesus were valid only for the period before the coming of the final end, a sign of real repentance. Building his arguments on the mission of the disciples in Matthew 10 and sayings such as: 'I tell you there are some here who will not die until they have seen the Kingdom of God come with power' (TEV), Schweitzer came to the conclusion that the failure of the kingdom to arrive caused a turning point in the life of Jesus. He did not expect his disciples back before the coming of the kingdom, but when this did not happen, he changed his mind. Jesus decided to hasten the sufferings of which we read in Matthew 10, and deliberately went to Jerusalem to provoke the authorities to kill him so that he could be transformed into the eschatological Son of man by the intervention of God (see Perrin 1963:31).

Subsequent research rejected many of Schweitzer's arguments, especially Jesus' change of mind, but retained the conceptual model of eschatology or apocalyptic. 
Because of the ambiguity in the Jesus tradition concerning the present and the future aspects of the kingdom, different explanations were devised of which the socalled 'realised eschatology' model of the British scholar C H Dodd is the most influential.

Dodd accepted the general consensus that the 'kingdom of God' was an apocalyptic concept. He, however, asserted that for Jesus the kingdom was present in his own ministry, thus realised. He also argued that those sayings which refer to the future coming of the kingdom do not refer to a future coming in this world, since it has already fully arrived in the ministry of Jesus; they refer to something beyond time and space as an ultimate fulfilment in a world beyond this one (see Perrin 1963:58).

Many scholars after Dodd paid attention to the present and future aspects of the kingdom of God and consensus started growing concerning the arrival of the kingdom in the ministry of Jesus. In this way a hermeneutical framework - that is, a framework of understanding - came into being both by interpreting the Jesus tradition in terms of Jewish expectations of the end of the world, and by consensus among scholars. Jesus and the early Christians were seen as people who expected the end of the world soon.

The important point I would like to emphasise for our purpose is the fact that scholars reached agreement on the frame of reference within which the Jesus tradition had and has to be interpreted. Almost everything that he said and did has to be interpreted within this frame of reference. Let us, however, take the matter a little further.

One of the most thorough interpretations of Jesus as an eschatological prophet in recent times is that of Sanders, to whom I referred in my previous essay (see Sanders 1985). He argues that Jesus (and his disciples) expected the coming of the kingdom in the near future and also that they would play an important role in the kingdom (Sanders 1985:118). He built his case on a thorough interpretation of aspects of the expectation of the restoration of Israel in the ministry of Jesus.

He starts his argument with an analysis of Jesus and the temple. According to him the cleansing of the temple should be interpreted as a symbolic act signifying the destruction of the temple. But destruction obviously points to restoration, which is confirmed by the sayings of Jesus on the destruction of the temple. 'He [Jesus] intended...to indicate that the end was at hand and that the temple would be destroyed, so that the new and perfect temple might arise' (Sanders 1985:75). In other words, Jesus proclaimed the restoration of the temple and of Israel. Like the prophets of old he proclaimed the plan of God, destruction and restoration. It is this thesis that forms the backbone of Sanders's study. 
Turning to other indications of restoration eschatology, Sanders argues that Jesus first became a follower of John the Baptist who was an eschatological prophet. He, however, saw his own ministry as being the proclamation of the kingdom 'which, it would appear, he regarded as the next final step in God's plan of redemption', and saw himself as engaged in the final act of history (Sanders 1985:93). The Twelve also point to Jesus' understanding of his task as including the restoration of Israel. Although national repentance and judgement do not play such a significant role in his teaching, there is some indication that Jesus fits well in the role of a prophet with the eschatological expectation of the restoration of Israel.

Sanders (1985:124) is convinced that the distinctiveness of the first-century world-view is that it was eschatological, in the apocalyptic sense of the word, and that Jesus shared this view. He accordingly interprets the theme of the kingdom of God in the teaching of Jesus with respect to this world-view. The term refers to the ruling power of God (Sanders 1985:126), and is used in the teaching of Jesus referring both to the present and to the future. This major problem of New Testament interpretation is solved differently by scholars. For Sanders the emphasis is in the end on the future coming of the kingdom. Jesus expected the kingdom in the immediate future (Sanders 1985:152).

In short, most of what we know about Jesus makes one think that he fits well into the role of a prophet of restoration according to Sanders (1985:222). John the Baptist called on the whole of Israel to repent before the coming judgement and Jesus started his career as a follower of John. Jesus called twelve disciples, which points to the restoration of Israel. In accordance with the Jewish expectation of restoration Jesus expected the temple to be destroyed and restored. And after his death and resurrection the disciples worked within such a framework.

It is undoubtedly possible that Jesus was an eschatological prophet in first-century Galilee. The Jewish historian, Josephus, witnesses to this fact (see Feldman 1988 and also Hengel 1981). Whether he was in fact such a prophet is another matter. Sanders's study is obviously directly influenced by the Jewish eschatological framework into which he fits Jesus. His arguments are directed by this model of interpretation. And within this framework his image of Jesus as an eschatological prophet makes sense. The question therefore remains: how valid is this framework?

\section{JESUS THE WISDOM TEACHER}

I have noted above that the eschatological framework into which Jesus and his teaching have been fitted during the past century has been called into question in the recent past on several grounds. In this section I shall pay attention to the possibility of viewing Jesus as a sage or a teacher of wisdom in first-century Palestine. 
There are many indications in the synoptics that Jesus was regarded as a teacher. According to Mark (4:38 et al), one of his main activities was to teach the disciples and other people. Mark says that people regarded his teaching as 'new' and that it amazed them (Mk 1:27; see Mt 7:28; $22: 33$ et al). His disciples called him 'teacher' (Mt 8:19 et al) and his teaching was put into long speeches by the authors of the Gospels (see Mt $5 \mathrm{ff}$ ). Our sources tell us that he taught in synagogues (Mt 4:23 et al), at the sea shore (Mk 4:1) and in many other places, giving the impression that he was an itinerant teacher. He was, however, also called 'rabbi' (Mk 9:5 et al) and the question immediately arises as to what kind of teacher he was. This is not a simple question and we will have to consider it thoroughly.

The synoptic tradition does not tell us that Jesus taught in a school or that he had a regular group, except for the disciples, whom he educated. Therefore we have to go to the form and content of his teaching to see whether we can in any way discern what kind of teacher he was.

The teaching of Jesus, as we have it in the Gospels, consists of his sayings, which are given on their own sometimes in groups, embedded in short stories, dialogues and longer speeches. An important part of the sayings material consists of parables, proverbs, metaphors and so on. In short, a great deal of Jesus' teaching was done in aphoristic form - short pithy sayings - expressing a general truth, as I have said above, and embedded in different contexts. Consider the following:

Do not store up riches for yourselves here on earth, where moths and rust destroy, and robbers break in and steal. Instead, store up riches for yourselves in heaven, where moths and rust cannot destroy, and robbers cannot break in and steal. For your heart will always be where your riches are.

The eyes are a lamp for the body. If your eyes are sound, your whole body will be full of light; but if your eyes are no good, your body will be in darkness. So if the light in you is darkness, how terribly dark it will be!

No one can be a slave of two masters; he will hate one and love the other; he will be loyal to one and despise the other. You cannot serve both God and money. This is why I tell you not to be worried about the food and drink you need in order to stay alive, or about clothes for your body. After all, isn't life worth more than food? And isn't the body worth more than clothes? Look at the birds: they do not sow seeds, gather a harvest and put it in barns; yet your father in heaven takes care of them! Aren't you worth much more than birds? Can 
any of you live a bit longer by worrying about it? And why worry about clothes? Look how the wild flowers grow: they do not work or make clothes for themselves. But I tell you that not even King Solomon with all his wealth had clothes as beautiful as one of these flowers. It is God who clothes the wild grass - grass that is here today and gone tomorrow, burnt up in the oven. Won't he be all the more sure to clothe you? How little faith you have! So do not start worrying: 'Where will my food come from? or my drink? or my clothes?' [These are the things the pagans are always concerned about.] Your Father in heaven knows that you need all these things. Instead, be concerned above everything else with the Kingdom of God and with what he requires of you, and he will provide you with all these other things. So do not worry about tomorrow; it will have enough worries of its own. There is no need to add to the troubles each day brings.

(Mt 6:19-34, TEV)

Examples of this type of aphoristic teaching of Jesus can be multiplied. They give the impression that they were given by somebody who was able to offer instruction about practical skills to cope with different situations in life. The sayings of Jesus often contain values for ethical conduct and the pursuit of a lifestyle which is worth following. That is why it is necessary to determine what kind of teacher would have given such instruction.

The aphoristic nature of the teaching of Jesus reminds one of the Proverbs of the Old Testament and other wisdom texts. Wisdom, however, refers to many things and before we draw any conclusions it is necessary to pay attention to what we mean by wisdom and whether it is possible to call Jesus a teacher of wisdom.

Wisdom ranges from practical skills such as those of the craftsman, the art of government, cleverness, the skill to cope with life, and the pursuit of ethical conduct. It belongs to God and is associated with creation and the Law in the Old Testament (see Murphy 1985:1135). It is a term which is applied to a variety of things: 'an insight into the world, a spirituality..., a literature' (Humphrey 1989:50). Like other theologies, wisdom theology is a perspective on God and the world. Unlike eschatological and apocalyptic theology it does not focus on the end of the world. It focuses on this world and its orderliness. God is the giver of wisdom and the wise one is the person who finds wisdom and lives according to it.

Although the New Testament does not have an example of wisdom literature the phenomenon is definitely not absent. This is especially true of the teaching of Jesus. He was regarded as a sage who was even wiser than Solomon (Lk 11:31), and 
as we have seen, much of his teaching was given in aphoristic form, which is typical of wisdom teaching. Both the form and the content of the teaching of Jesus make it possible to view him as a wisdom teacher. The teaching is presented in the synoptics as that of a sage who instructs and exhorts people on many topics, including happiness, love of one's enemies, doing good, blessing, praying, turning the other cheek, offering one's cloak, generous lending, applying the golden rule, mercy and many other things.

We have noted above that it is not possible to answer the question of who Jesus was by taking the Gospels at face value. It is therefore necessary to pursue the image of Jesus as a wisdom teacher a little further.

I have referred above to the growth of the Gospel tradition and have made mention of the hypothetical source Q. Q mainly consists of the teaching of Jesus in the form of sayings. It probably did not contain much narrative material and was therefore totally different from the synoptics and John, which present the Jesus material in narrative form. Like the Gospel of Thomas, $Q$ presents Jesus as teacher. $Q$ is therefore currently regarded as part of the sapiential literature like Proverbs and other texts. In its oldest form $Q$ probably only contained wisdom material. It implies that one of the oldest ways of viewing Jesus was to see him as a wisdom teacher who gave instructions and admonitions (see Kloppenborg 1987). Did the compiler of $Q$ preserve an authentic image of Jesus, perhaps the authentic picture of Jesus?

From the viewpoint of first-century Jewish theology it is undoubtedly possible that Jesus could have been a wisdom teacher who was interested in instructing people on how to cope with life and pursue ethical conduct. Wisdom was a traditional perspective in Jewish theology and wisdom thinking was 'in the air', so to speak, in the first century. This can be seen from the works of the Greek popular philosophers, but also from the Jewish-Hellenistic authors of the period (see Kloppenborg 1987; Mack 1987). Wisdom forms part of the culture of the period and it is not impossible to see Jesus in the religious role of a wisdom teacher travelling around in Galilee instructing people on how to live a meaningful life by changing their value systems (see Theissen 1989). Galilee was a place where people of different walks of life, in different life situations, and of different cultures were gathered during the time of Jesus. That is why one has to see the earthly Jesus first of all in that context and not in the context of the Jerusalem cult. Mack (1988:608) maintains that: 'A Cynic Jesus does appear to fit the Hellenistic cast to Galilean culture much better than the apocalyptic Jesus.'

The question might immediately arise: what about the term 'kingdom of God' in the teaching of Jesus? Is it not an eschatological term? And does it not mean that the wisdom teaching of Jesus should be seen within that framework? 
'Kingdom of God' is a very complex term and scholars do not agree on its meaning and reference. Generally speaking, there is consensus that it simply means the rule of God. But what it refers to in the teaching of Jesus is quite another matter. This is not the place to go into detail. Mack has made it clear that it is not necessary to understand the term exclusively in eschatological terms and that the eschatological interpretation is dependent upon Mark's apocalyptic presentation of Jesus. Building on the work of Perrin he reminds us that Perrin has shown that 'kingdom of God' is not a concept that occurs very often in apocalyptic texts and that only four of the kingdom of God sayings which are ascribed to Jesus could have any claim to authenticity, namely Mark 1:15a, Luke 11:20, Luke 17:20-21, and Matthew 11:12 (Mack 1987:10). Mack puts the term into a larger cultural context and shows that 'kingdom' is what rulers had - that is, 'sovereignty, majesty, dominion, power, domain' (Mack 1987:11). He argues that 'kingdom' became a metaphor for sovereignty, freedom, and confidence, which were typical characteristics of the sage in popular Stoic and Cynic philosophy. The sage is the only ruler as Philo says. 'Kingdom of God' would not have called up apocalyptic images in this type of context. It would have been interpreted rather within the framework of wisdom. Mack (1988) has convincingly shown that it is unnecessary to interpret the term 'kingdom of God' eschatologically in the oldest layer of $Q$. It has to be interpreted as part of the wisdom teaching of Jesus.

Noteworthy is the fact that the three instances in which the term occurs outside early Christian texts are found in Hellenistic-Jewish texts. The following example from the Sentences of Sextus 307-311, as quoted by Mack (1987:15), is worth mentioning, even though the document is not from the same period as the synoptics:

A wise man presents god to humanity.

Of all his works, god is most proud of a sage.

Next to god, nothing is as free as a wise man.

A wise man shares...in the basileia tou theou.

If Jesus were a sage he could have used the term 'kingdom of God' to underscore the sovereignty and rule of God in wisdom terms. The idea that God was ruling was common to traditional Jewish thought although it was not often expressed in terms of the 'kingdom of God'. The term 'kingdom of God' is unusual in Aramaic and as Perrin (1967:38) maintains, it 'would never be found in Aramaic'.

The many occurrences of the term 'kingdom of God' in the teaching of Jesus probably point to the fact that he used the term. To my mind it stands for the rule of God and it was used by Jesus as one of the leading symbols in his instruction. 
One should see it as part of the conviction of Jesus that one should acquire the skill of becoming wise.

Taking into account the evidence of the synoptics, it seems possible to see Jesus as a wisdom teacher. Does that, then, mean that he was not a prophet?

\section{JESUS: ESCHATOLOGICAL PROPHET AND/OR WISDOM TEACHER?}

Answers to the question of who Jesus was differ greatly in terms of eschatological/ apocalyptic or wisdom theology. It is obvious from our sources that Jesus was a charismatic leader who succeeded in making followers and changing ideas. He performed miracles and taught people how to live a happy life in accordance with the will of God. But who was he? Did he fit the roles of both a preacher and a wisdom teacher, or was he one and not the other? If we consider the different frameworks within which he should have fitted if he were both, they involve the following: preaching and teaching, prophetic proclamation and rhetorical persuasion, eschatology or apocalyptic and wisdom (see Mack 1988).

It is possible that prophetic proclamation could include the genre of wisdom. One should therefore not make it an either/or situation from the outset. On the other hand, one should also ask whether eschatology/apocalyptic and wisdom are not two totally different perspectives on life. While the prophet is a channel through which the divine communicates and proclaims what is right and wrong in the current situation and what will happen in the future, the wisdom teacher is somebody who instructs people on how to live a meaningful life. With regard to Jesus one should therefore start at another point. Perhaps the most appropriate point is the fact that our sources do not give us a historical picture of who he was. They tell us about his significance, about his reputation, but not of who he was. Let us therefore consider the question from another angle.

The cornerstone of the conviction that Jesus and his ministry should be interpreted eschatologically comprises the 'coming Son of man' sayings. They also form the basis for the eschatological interpretation of the concept 'kingdom of God'. A number of the sayings of Jesus speak of the future coming of the 'Son of man'. This figure is portrayed as someone who will play an important role in the final judgement:

If a person is ashamed of me and of my teaching in this godless and wicked day, then the Son of Man will be ashamed of him when he comes in the glory of his Father with the holy angels.

(Mk 8:38, TEV) 
These and similar sayings convinced scholars that Jesus thought the final judgement and the end of the world to be imminent. The point, however, is whether these sayings are authentic Jesus sayings or whether they are based on an apocalyptic interpretation of Jesus, and therefore put on his lips. There is growing consensus that Jesus referred to himself as the 'son of man', that is, 'I' or 'man', but that the future 'Son of man sayings' are not authentic (see Borg 1986:87ff). If this is the case, the main cornerstone of the eschatological Jesus becomes problematic.

The term 'kingdom of God' is also not essentially an eschatological term. It simply refers to the reign of God, his sovereignty. Because it is normally conceived of in terms of an eschatological framework in the teaching of Jesus, it is interpreted eschatologically and apocalyptically as we have seen above. There seems to be little, if anything, compelling in the conviction that the term should be interpreted eschatologically. Without the coming Son of man sayings, its eschatological interpretation is without foundation. The implication is that eschatological interpretation of Jesus and the kingdom of God in the light of the coming 'Son of man' sayings becomes questionable. It also means that the image of Jesus as an eschatological prophet becomes problematic. However, much research has to be done before we can reach a totally convincing conclusion about Jesus having been an eschatological prophet. As I have said, for a century scholars have been convinced that the teaching of Jesus was couched in Jewish eschatological hopes. It is too early to make final judgements as to whether Jesus was an eschatological prophet or a wisdom teacher. There are many other things involved which also have to be accounted for. Let us consider the following.

One of the most important facts in the life of Jesus was that he was baptised by John and that he then became a follower of John. John was an eschatological prophet who proclaimed repentance and judgement. The question therefore arises as to what the relationship was between John and Jesus. Was John the final eschatological figure or was he the forerunner of the final figure, as the followers of Jesus took him to be after the death of Jesus?

According to our sources there are obvious differences between John and Jesus. While John was an ascetic, living and preaching in the desert, Jesus mixed with sinners and was regarded as a wine drinker and a glutton. John's mission was to separate the wheat from the chaff, and his disciples fasted, while Jesus and his disciples apparently did not. Jesus' mission was to include sinners, while John called for the repentance of the nation. It is thus possible that Jesus embarked on a mission quite different from that of John when he started 'preaching' the gospel in Galilee. To me it seems possible, as Boers (1989) has indicated, that the followers of Jesus, unlike Jesus himself, regarded him as the final eschatological figure after his death. 'Jesus 
understood the kingdom of God to have been inaugurated by John the Baptist, which meant that it had already arrived, whereas his followers expected its coming with the return of Jesus as the Son of Man, which placed it in future' (Boers 1989: 45). This implies that Jesus embarked on a mission of making the 'kingdom of God' known to the people. Unlike John he did not preach as an eschatological preacher. He instructed people about the skills of life in the kingdom. Whoever was willing to listen to him could acquire a new value system. He created a symbolic reality for people who were distressed and lost and oppressed, and gave them reason to find life meaningful.

The time is ripe to reconsider fundamentally the question of who Jesus was. It is too early to say whether we are misled by the eschatological lens through which early Christians like the first followers and Mark saw him after his death. Much more has to be done on the wisdom trajectory before we can say with any certainty that Jesus was not an eschatological prophet, and that he was a wisdom teacher.

The teaching of Jesus was radical. It was not revolutionary in the modern sense of the word. He was mistaken by the Romans as a messianic pretender and a danger to the Empire, and was killed on the cross. After his death he was put into many religious roles because of his significance for his followers. Before his death he enabled people, by his teaching, to cope with life and to pursue a lifestyle in accordance with his perception of the will of God.

\section{Works cited}

Boers H 1989. Who was Jesus? The historical Jesus and the Synoptic Gospels. San Francisco: Harper \& Row.

Borg, M J 1986. A temperate case for a non-eschatological Jesus. Foundations \& Facets Forum 2, 81-102.

Feldman, L H 1988. Prophets and prophecy in Josephus, in SBL 1988 seminar papers, 425-441. Atlanta: Scholars Press.

Guelich, R A 1976. The Matthean beatitudes: 'Entrance-requirements' or eschatological blesssings? JBL 95, 415-434.

Hengel, M 1981. The charismatic leader and his followers. Edinburgh: T \& T Clark. Humphrey, H M 1989. Jesus as wisdom in Mark. BThB 19,48-53.

Kloppenborg, J S 1987. The formation of Q: Trajectories in ancient wisdom collections. Philadelphia: Fortress.

Mack, B L 1987. The kingdom sayings in Mark. Foundations \& Facets Fonum 3, 347. 
Mack, B L 1988. The kingdom that didn't come: A social history of the $Q$ tradents, in SBL 1988 seminar papers, 608-635. Atlanta: Scholars Press.

Murphy, R E 1985. s v 'Wisdom'. Harper's Bible Dictionary.

Perrin, N 1963. The kingdom of God in the teaching of Jesus. London: SCM.

.-. 1967. Rediscovering the teaching of Jesus. London: SCM.

Sanders, E P 1985. Jesus and Judaism. Philadelphia: Fortress.

Theissen, G 1989. Jesusbewegung als charismatische Weltrevolution. NTS 35, 343360.

Vorster, W S 1991. Jesus the Galilean. HTS 47, 121-135.

Wilson, R R 1985. s v 'Prophet'. Harper's Bible Dictionary. 